\title{
Stability and cytotoxicity of angiotensin-I-converting enzyme inhibitory peptides derived from bovine casein *
}

\author{
Wei WU, Pan-pan YU, Feng-yang ZHANG, Hong-xia CHE, Zhan-mei JIANG ${ }^{\dagger *}$ \\ (Key Laboratory of Dairy Science, Ministry of Education, College of Food Science, \\ Northeast Agricultural University, Harbin 150030, China) \\ †E-mail: zhanmei.jiang@gmail.com
}

Received Sept. 4, 2013; Revision accepted Dec. 1, 2013; Crosschecked Jan. 21, 2014

\begin{abstract}
This study investigated the effect of heat treatment combined with acid and alkali on the angiotensin-Iconverting enzyme (ACE) inhibitory activity of peptides derived from bovine casein. The free amino group content, color, and cytotoxicity of the peptides were measured under different conditions. When heated at $100{ }^{\circ} \mathrm{C}$ in the pH range from 9.0 to 12.0, ACE inhibitory activity was reduced and the appearance of the peptides was significantly darkened. After thermal treatment in the presence of acid and alkali, the free amino group content of ACE inhibitory peptides decreased markedly. High temperature and prolonged heating also resulted in the loss of ACE inhibitory activity, the loss of free amino groups, and the darker coloration of bovine casein-derived peptides. However, ACE inhibitory peptides, within a concentration range of from 0.01 to $0.2 \mathrm{mg} / \mathrm{ml}$, showed no cytotoxicity to Caco-2 and ECV-304 cell lines after heat treatment. This indicated that high temperature and alkaline heat treatment impaired the stability of bovine casein-derived ACE inhibitory peptides.
\end{abstract}

Key words: Angiotensin-I-converting enzyme inhibitory peptide, Heat treatment, Stability, Cytotoxicity doi: $10.1631 /$ jzus.B1300239

Document code: A

CLC number: S872

\section{Introduction}

Angiotensin-I-converting enzyme (ACE; EC 3.4 15.1) is an important enzyme in the renin-angiotensin system, which plays a pivotal role in the regulation of blood pressure. The enzyme raises blood pressure by catalyzing the conversion of inactive angiotensin-I to angiotensin-II, a powerful endogenous vasoconstrictor. It is also involved in the release of a sodiumretaining steroid and aldosterone from the adrenal

\footnotetext{
ॠCorresponding author

* Project supported by the Innovative Research Team of Higher Education of Heilongiang Province (No. 2010td11), the National Natural Science Foundation of China (No. 31000801), the National Key Technology R\&D Program of China during the 12th Five-Year Plan Period (No. 2013BAD18B06), and the 2009 Doctoral Science Research of Northeast Agricultural University, China

(c) Zhejiang University and Springer-Verlag Berlin Heidelberg 2014
}

cortex, which has a tendency to stimulate blood vessels to shrink and increase blood pressure (Ondetti and Cushman, 1982). Increased serum ACE levels are associated with hypertension and other diseases, such as congestive heart failure, left ventricular hypertrophy, and acute myocardial infarction (Roškar et al., 2009). Captopril, lisinopril, enalapril, and fosinopril are chemically synthesized pharmaceuticals commonly used in the treatment of hypertension (Atkinson et al., 1980). However, these synthetic ACE inhibitors may cause side effects, such as coughing, taste disturbances, skin rashes, and angioneurotic edema. In addition, their use may lead to the aldosterone escape phenomenon and reduce the efficacy of ACE inhibitors after a long-term administration (Chen et al., 2012).

Many studies on ACE inhibitors from food sources have been undertaken since the first ACE 
inhibitor was isolated from snake venom (Ferreira, 1965). It was first reported that peptides derived from digests of gelatin exhibited ACE inhibitory activity (Oshima et al., 1979). Subsequently, ACE inhibitory peptides have been prepared from many other food sources such as soy, milk, fish muscle, and cereals (Ichimura et al., 2003; Zhang et al., 2006; Costa et al., 2007; Tovar-Pérez et al., 2009). ACE inhibitory peptides may have broad application in the treatment of hypertension ( $\mathrm{Li}$ et al., 2004), due to their potential physiological and pharmacological effects.

During the past decade, food scientists have obtained ACE inhibitory peptides from different food sources by a variety of methods, and have developed a complete system for their preparation, separation, and purification (Jang and Lee, 2005; Chen et al., 2007; Lee et al., 2009; Jiang et al., 2010). Heat treatment is one of the most common processing steps in the food industry, and is commonly used for food safety, drying, or stabilization purposes. It is unclear whether ACE inhibitory peptides would maintain their inhibitory activities, change their chemical composition, produce browning, or cause toxicity during heat treatment of food during processing in the presence of acid or alkali. In this study, we tested ACE inhibitory peptides derived from bovine casein that had been validated as having strong antihypertensive activity (Jiang et al., 2010). The objective of this study was to evaluate the processing stability and cell viability of bovine casein-derived ACE inhibitory peptides under different heat treatments. The results might be useful in evaluating the use of ACE inhibitory peptides from bovine casein as active ingredients in functional foods with potential antihypertensive effects.

\section{Materials and methods}

\subsection{Materials}

Bovine casein was prepared from bovine milk using an isoelectric precipitation method developed by the Key Laboratory of Dairy Science, Northeast Agricultural University, Harbin, China. AS1.398 neutral protease (from Bacillus subtilis; activity $50000 \mathrm{U} / \mathrm{g}$ ) was purchased from the Wuxi Enzyme Preparation Company (Wuxi, China). Caco-2 cells (TCHu146), a human colon adenocarcinoma cell line, were purchased from the Shanghai Institutes for
Biological Sciences of the Chinese Academy of Sciences. Human umbilical vein endothelial ECV304 cell lines were provided by Dr. Shu-jing WANG from Harbin University of Commerce, China. Hippuryl-L-hisstidyl-L-leucine (Hip-His-Leu), ACE, hippuric acid (HA), o-phthaldialdehyde (OPA), L-leucine, $\beta$-mercaptoethanol, 3-(4,5-dimethythiazol2-yl)-2,5-diphenyltetr-azolium bromide (MTT), and sodium dodecyl sulphate (SDS) were purchased from Sigma-Aldrich Co. (USA). All other reagents were of analytical grade.

\subsection{Preparation of bovine casein-derived ACE inhibitory peptides}

ACE inhibitory peptides were prepared by the method of Jiang et al. (2010). Casein (75 g/L) was dissolved in $\mathrm{pH} 7.0,0.04 \mathrm{~mol} / \mathrm{L}$ phosphate buffer. Hydrolysis was initiated by addition of AS1.398 neutral protease at $45^{\circ} \mathrm{C}$ and the enzyme concentration was fixed at $5 \%(\mathrm{w} / \mathrm{w}$ protein). The $\mathrm{pH}$ value was kept at 7.0 by continuous addition of $1 \mathrm{~mol} / \mathrm{L} \mathrm{NaOH}$. After the hydrolysis reaction, the protein hydrolysates were heated at $95{ }^{\circ} \mathrm{C}$ for $20 \mathrm{~min}$ to inactivate this enzyme and then centrifuged at $4000 \mathrm{~g}$ for $20 \mathrm{~min}$ at $4{ }^{\circ} \mathrm{C}$. Subsequently, the supernatants were ultrafiltrated through a $3-\mathrm{kDa}$ molecular weight cut-off membrane (Millipore Co., USA) at $35{ }^{\circ} \mathrm{C}$ under a pressure of $3 \mathrm{MPa}$. The resulting permeates were collected and lyophilised to obtain the bovine caseinderived ACE inhibitory peptides.

\subsection{Stability of bovine casein-derived ACE inhi- bitory peptides}

To investigate the effect of temperature, samples of bovine casein-derived ACE inhibitory peptide solutions $(80 \mathrm{~g} / \mathrm{L})$ were adjusted to $\mathrm{pH} 7.0$ and heated at $40,60,80,90,100,110$, or $120^{\circ} \mathrm{C}$ for $2 \mathrm{~h}$. To investigate the effect of $\mathrm{pH}$, peptide solutions were heated at $100^{\circ} \mathrm{C}$ at $\mathrm{pH}$ values of $1.0,2.0,3.0,4.0,5.0$, $6.0,7.0,8.0,9.0,10.0,11.0$, or 12.0 for $1 \mathrm{~h}$. To investigate the effect of the duration of heat treatment, peptide solutions were adjusted to $\mathrm{pH} 7.0$ and incubated at $100{ }^{\circ} \mathrm{C}$ for $0.5,1.0,2.0,3.0$, or $4.0 \mathrm{~h}$. Unheated peptides were used as controls. In all the experiments, each treatment was carried out using triplicate samples. 


\subsection{Determination of ACE inhibitory activity}

ACE inhibitory activity was measured by highperformance liquid chromatography (HPLC), using a modification of the method of Cushman and Cheung (1971). For each assay, a mixture containing $120 \mu \mathrm{l}$ of $5.0 \mathrm{mmol} / \mathrm{L}$ Hip-His-Leu dissolved in $50 \mathrm{mmol} / \mathrm{L}$ sodium borate buffer $(\mathrm{pH} 8.3)$ and $20 \mu \mathrm{l}$ of peptide solution was preincubated at $37{ }^{\circ} \mathrm{C}$ for $5 \mathrm{~min}$. ACE solution $(100 \mathrm{U} / \mathrm{L})$ of $10 \mu \mathrm{l}$ was then added to the mixture and incubated at $37{ }^{\circ} \mathrm{C}$ for $1 \mathrm{~h}$. Thereafter, the reaction was terminated by the addition of $150 \mu \mathrm{l}$ of $1 \mathrm{~mol} / \mathrm{L} \mathrm{HCl}$. Reaction samples were filtered through $0.45 \mu \mathrm{m}$ filters and $50 \mu \mathrm{l}$ were injected. Hippuric acid liberated by ACE was determined by reverse-phase HPLC (RP-HPLC) onto a Yilite SinoChrom ODS-BP C18 column $(250 \mathrm{~mm} \times 4.6 \mathrm{~mm}$ i.d., $5 \mu \mathrm{m}$, Dalian, China) at $30{ }^{\circ} \mathrm{C}$. A linear gradient from $20 \%$ to $70 \%$ acetonitrile containing $0.1 \%$ trifluoroacetic acid (TFA) was applied in $10 \mathrm{~min}$, and then from $70 \%$ to $0 \%$ acetonitrile containing $0.1 \%$ TFA was reached in $2 \mathrm{~min}$. Flow rate was $1.0 \mathrm{ml} / \mathrm{min}$ and elution was monitored at $228 \mathrm{~nm}$. In all experiments, each treatment was carried out with triplicate samples. The percentage of ACE inhibitory activity was calculated as $\left(A_{0}-A_{1}\right) \times 100 \% / A_{0}$, where $A_{0}$ represents the absorbance of hippuric acid without the sample and $A_{1}$ represents the absorbance of hippuric acid with the sample.

\subsection{Determination of free amino groups}

The content of free amino groups was determined by the OPA method with some modifications (Church et al., 1983). The OPA reagent was prepared to a final volume of $100 \mathrm{ml}$ with deionized water, and consisted of $5.0 \mathrm{ml}$ of $200 \mathrm{mg} / \mathrm{L} \mathrm{SDS}, 80 \mathrm{mg}$ of OPA in $2 \mathrm{ml}$ methanol, $200 \mu \mathrm{l}$ of $\beta$-mercaptoethanol, and

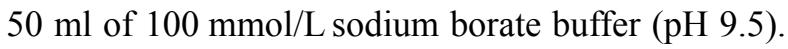
Then, $3 \mathrm{ml}$ of OPA reagent was mixed with $100 \mu \mathrm{l}$ of $2 \mathrm{mg} / \mathrm{L}$ ACE inhibitory peptide solution. After vortexing and a minimum 5 min delay in darkness at room temperature, the absorbance was recorded at $340 \mathrm{~nm}$ by an ultraviolet (UV) spectrophotometer (UV-2401PC, Shimadzu, Japan). Calibration curves were obtained by using $0-0.55 \mathrm{~g} / \mathrm{L}$ leucine as a standard, and absorbance readings were converted into free amino group contents. The changes in free amino groups were expressed as relative concentrations (\%) in comparison with the content of such groups in unheated ACE inhibitory peptides.

\subsection{Determination of color}

Colormetric measurements of ACE inhibitory peptide samples were made using an SE-2000 color difference meter (Nippon Denshoku Industries Co., Ltd., Japan). The color difference meter provides the values of three color components: the $L^{*}$ value represents black and white components, the $a^{*}$ value represents red to green components, and the $b^{*}$ value represents yellow to blue components. Samples of $2 \mathrm{ml}$ with a concentration of $20 \mathrm{mg} / \mathrm{ml}$ were measured in a quartz cuvette. All samples of each treatment were read six times.

\subsection{Cell culture and cell viability assay in vitro}

The cell viability of ACE inhibitory peptides was determined by MTT assay against Caco- 2 and ECV-304 cell lines. The two kinds of cells were cultured in Dulbecco's modification of Eagle's medium (DMEM; GIBCO, USA) containing $100 \mathrm{U} / \mathrm{ml}$ penicillin, $100 \mathrm{~g} / \mathrm{ml}$ streptomycin, and $100 \mathrm{ml} / \mathrm{L}$ fetal bovine serum (FBS), and maintained at $37{ }^{\circ} \mathrm{C}$ in a humidified atmosphere with $5 \% \mathrm{CO}_{2}$. Cells in logarithmic growth were chosen and cultured in the 96-well plates at a density of $2.5 \times 10^{3}$ cells per well. When confluence was up to $60 \%-70 \%$, the culture solutions were removed and freshly prepared DMEM, with different concentrations of ACE inhibitory peptides, was added to the plates. After incubation for $48 \mathrm{~h}, 20 \mu \mathrm{l}$ of $5 \mathrm{mg} / \mathrm{ml}$ MTT solutions was added to each well and cultivation continued for $4 \mathrm{~h}$. Afterwards, the MTT solutions were carefully removed and $150 \mu \mathrm{l}$ of dimethylsulphoxide (DMSO) was added to each well to dissolve the formazan crystals. The optical density was assayed with a microplate reader (Model 680, Bio-Rad Laboratories, Hercules, USA) at $490 \mathrm{~nm}$. The cell viability was calculated as $A_{\text {sample }} / A_{\text {control }} \times 100 \%$. All the MTT assays were repeated at least six times.

\subsection{Statistical analysis}

Three independent experiments were conducted to test the stability and cytotoxicity of ACE inhibitory peptides derived from bovine casein. One-way analysis of variance (ANOVA) and independent samples $t$-tests were conducted to determine the significance of the main effects, using the statistical analysis system SPSS 13.0 for windows (SPSS Inc., Chicago, IL). Data are expressed as mean \pm standard deviation (SD). 
Significant differences $(P<0.05)$ among means were identified using Duncan's multiple range tests and independent sample $t$-tests.

\section{Results and discussion}

\subsection{Effects of heat treatment on the ACE inhibi- tory activity of bovine casein-derived peptides}

Bovine casein-derived peptides can be delivered in the form of functional ingredients, or incorporated into other food products. During thermal processing, it is important to know whether their bioactivities can be maintained. The effects of different $\mathrm{pH}$ values $(1.0$ to 12.0) on the ACE inhibitory activity of bovine casein-derived peptides at $100{ }^{\circ} \mathrm{C}$ after $1 \mathrm{~h}$ of heat treatment are shown in Fig. 1a. There were no significant differences between the ACE inhibitory activity of the heated peptides in the $\mathrm{pH}$ range of 1.0 to 8.0 and that of unheated peptides $(P>0.05)$. This indicates that bovine casein-derived peptides can resist the acid or weak alkaline conditions of food processing. Hwang (2010) reported that tuna cooking juice-derived ACE inhibitory peptides had some resistance to the influence of $\mathrm{pH}$. Peptide mapping using HPLC showed slight differences before and after treatments at $\mathrm{pH} 2.0$ and 10.0. Similar results demonstrated that hendeca-peptide isolated from the pepsin hydrolysate of algae protein waste completely retained its ACE inhibitory activity in the $\mathrm{pH}$ range of 2.0 to 10.0 (Sheih et al., 2009). However, the ACE inhibitory activities of peptides noticeably decreased within the $\mathrm{pH}$ range of 9.0 to $12.0(P<0.05)$. When the $\mathrm{pH}$ value reached 12.0 , the peptides lost $20.16 \%$ ACE inhibitory activity, compared with the unheated controls. These results indicated that strong alkaline conditions could considerably reduce the ACE inhibitory activities of bovine casein-derived peptides. This is probably due to the degradation or hydrolysis of some peptides into inactive fragments under strong alkaline heating.

Heat treatment is the most important method in food processing. It causes protein denaturation and aggregation during temperature changes from 60 to $90{ }^{\circ} \mathrm{C}$ (Boye et al., 1997; Korhonen et al., 1998). Effects of different temperatures $\left(40\right.$ to $\left.120^{\circ} \mathrm{C}\right)$ on the ACE inhibitory activity of bovine casein-derived peptides at $\mathrm{pH} 7.0$ after $2 \mathrm{~h}$ of heat treatment are shown in Fig. 1b. There were no significant differ- ences in ACE inhibitory activity between bovine casein-derived peptides heated to $40-100{ }^{\circ} \mathrm{C}(P>0.05)$ and unheated peptides. Similarly, Jang et al. (2007) found that the activities of peptides DFHINQ and GFHI from beef sarcoplasmic protein extracts showed no significant change after heating at 70,80 , 90 , or $100{ }^{\circ} \mathrm{C}$ for $20 \mathrm{~min}$. In addition, the activity of soy protein-derived ACE inhibitory peptides retained its activity under various temperature treatments $(\mathrm{Wu}$ and Ding, 2002). However, some severe heat treatments of ACE inhibitory peptides, especially in preserve sterilization, might result in a decrease in activity due to the loss of available peptides compared

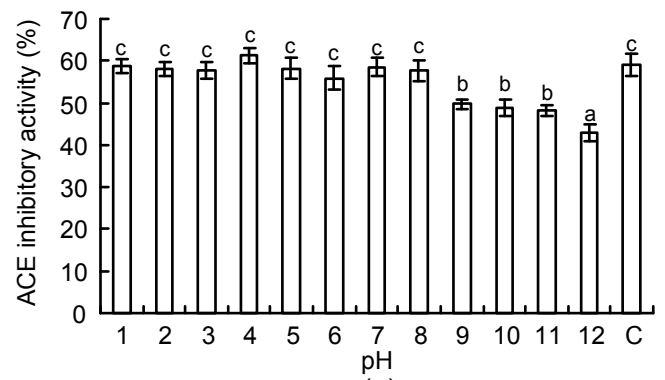

(a)

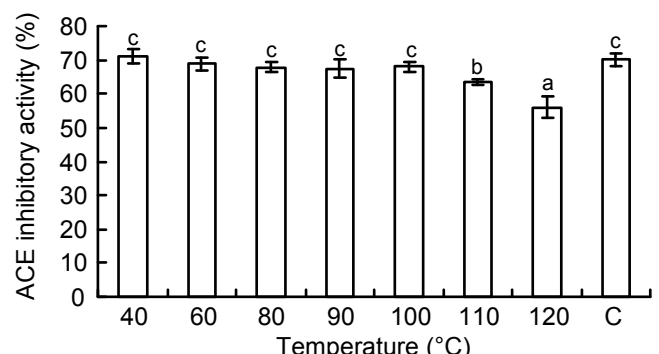

(b)

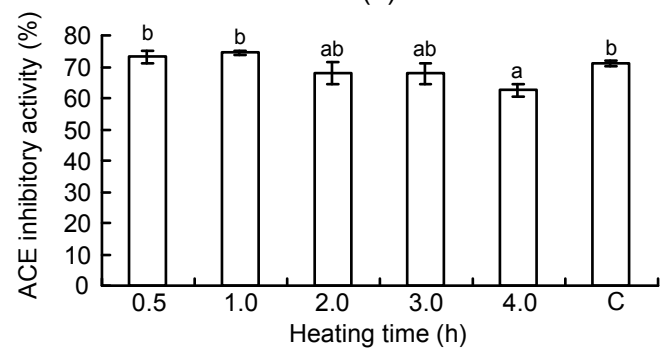

(c)

Fig. 1 Changes in inhibitory activity of ACE inhibitory peptides

(a) At different $\mathrm{pH}$ levels $(1.0-12.0), 100^{\circ} \mathrm{C}$ for $1 \mathrm{~h}$ of heat treatment; (b) At different temperatures $\left(40-120{ }^{\circ} \mathrm{C}\right)$, $\mathrm{pH} 7.0$ for $2 \mathrm{~h}$; (c) For different heating time $(0-4$ h) at $100{ }^{\circ} \mathrm{C}$ and $\mathrm{pH}$ 7.0. $\mathrm{C}$ denotes the ACE inhibitory peptides without heat treatment. Values are expressed as mean $\pm \mathrm{SD}$, $n=3$. Different letters above the bars are significantly different $(P<0.05)$ 
with other more mild treatments (Hwang, 2010). In this study, when bovine casein-derived peptides were heated at 110 and $120^{\circ} \mathrm{C}$, the ACE inhibitory activities of peptides decreased by about $6.55 \%$ and $14.14 \%$, respectively $(P<0.05)$, compared to that of unheated peptides. Therefore, temperature may be a crucial factor that may lead to the loss of ACE inhibitory activity of bovine casein-derived peptides. Nevertheless, the mechanism of the structure-activity relationship of ACE inhibitory peptides is still unclear The C-terminal sequence is known to be the factor that most strongly influences the binding to ACE. In addition, the inhibitory potency may be augmented by the presence of the positive charge of Lys and Arg as the $\mathrm{C}$-terminal residue. Thus, high heating may potentially alter the C-terminal sequence so that the ACE inhibitory activities of peptides are greatly affected (López-Fandino et al., 2006).

Heating time is also a major factor that may affect the ACE inhibitory activity of casein-derived peptides. The effects of different heating time ( 0.5 to $4.0 \mathrm{~h}$ ) on the ACE inhibitory activity of bovine casein-derived peptides at $100{ }^{\circ} \mathrm{C}$ and $\mathrm{pH} 7.0$ are shown in Fig. 1c. Compared to the unheated peptides, there was no statistically significant loss of ACE inhibitory activity in the bovine casein-derived peptides under heat treatments of 0.5 to $3.0 \mathrm{~h}(P>0.05)$, while heat treatment for $4.0 \mathrm{~h}$ slightly decreased activity $(P<0.05)$. The results showed that bovine casein-derived peptides could maintain ACE inhibitory activity for $3 \mathrm{~h}$ at $\mathrm{pH} 7.0$ and at $100{ }^{\circ} \mathrm{C}$. In contrast, Akıllıoğlu and Karakaya (2009) demonstrated that ACE inhibitory activity of legume species increased after heat treatment for $50 \mathrm{~min}$. Therefore, heating time may affect the biological activity of ACE inhibitory peptides.

\subsection{Effects of heat treatment on the free amino groups of bovine casein-derived ACE inhibitory peptides}

To assay the availability of free amino groups, the OPA method with some modifications was used to measure the content of free amino groups in bovine casein-derived ACE inhibitory peptides. Changes in free amino group content of bovine casein-derived peptides at different $\mathrm{pH}$ levels $(1.0$ to 12.0$)$ at $100{ }^{\circ} \mathrm{C}$ for $1 \mathrm{~h}$ are shown in Fig. 2a. In the $\mathrm{pH}$ range of 5.0 to 7.0, the content was maintained at $96.60 \%-104.69 \%$ of that of unheated samples. However, with increasing acidic and alkaline conditions, the content of free amino groups gradually declined $(P<0.05)$. When heated at $\mathrm{pH} 1.0$ and 12.0, bovine casein-derived peptides lost $14.28 \%$ and $24.19 \%$ of free amino groups, respectively. This indicated that extremely acidic or alkaline heat treatment could destroy some amino groups of ACE inhibitory peptides. This was probably caused by chemically oxidative deamination of amino groups of the peptides during the heat treatment combined with acidic or alkaline conditions. Furthermore, alkaline heat treatment consumed more amino groups of the bovine casein-derived peptides than acidic heat treatment. Alkaline heating may have accelerated the condensation of amino groups with carbonyl groups of small reducing sugars present in the peptide samples.

Changes in the free amino group content in the bovine casein-derived peptides at different temperatures $\left(40\right.$ to $\left.120^{\circ} \mathrm{C}\right)$ at $\mathrm{pH} 7.0$ for $2 \mathrm{~h}$ are shown in Fig. $2 b$. The free amino group content ranged from $98.27 \%$ to $83.29 \%$ with increasing temperature $(P<0.05)$. This suggests that high temperature treatment might also promote oxidative deamination of amino groups, leading to the loss of free amino groups from bovine casein-derived peptides.

Changes in the free amino group content of ACE inhibitory peptides derived from bovine casein heated for different time periods $(0$ to $4 \mathrm{~h})$ at $100{ }^{\circ} \mathrm{C}$ and pH 7.0 are shown in Fig. 2c. After half an hour, the content decreased by $5.90 \%$, compared to that of unheated peptides. There were no significant differences in the free amino group content $(P>0.05)$ within the first $1 \mathrm{~h}$. The loss of free amino groups increased when the heating time was prolonged to $4 \mathrm{~h}(P<0.05)$. Rada-Mendoza et al. (2006) found that considerable losses in free amino groups could be detected in $\beta$-lactoglobulin heated for $120 \mathrm{~h}$ at $80{ }^{\circ} \mathrm{C}$. These results indicate that prolonged heating time under high temperature conditions may increase or decrease the free amino group content of ACE inhibitory peptides of bovine casein.

\subsection{Effects of heat treatment on the color of bo- vine casein-derived ACE inhibitory peptides}

Color can be a visual expression of the extent of a reaction. When casein-derived ACE inhibitory peptides are dissolved in distilled water, the color of the 


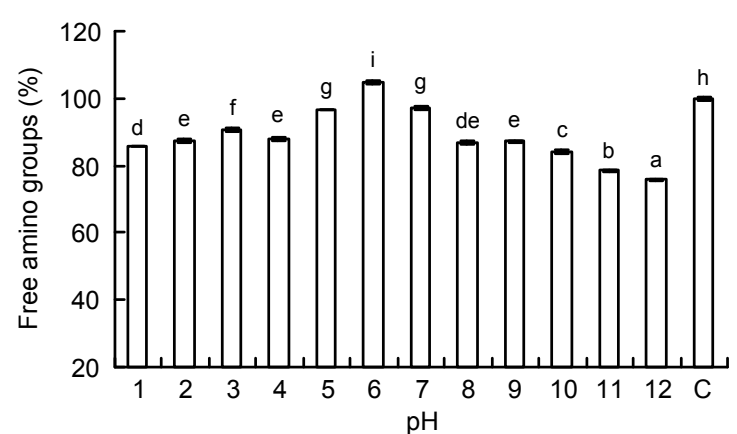

(a)

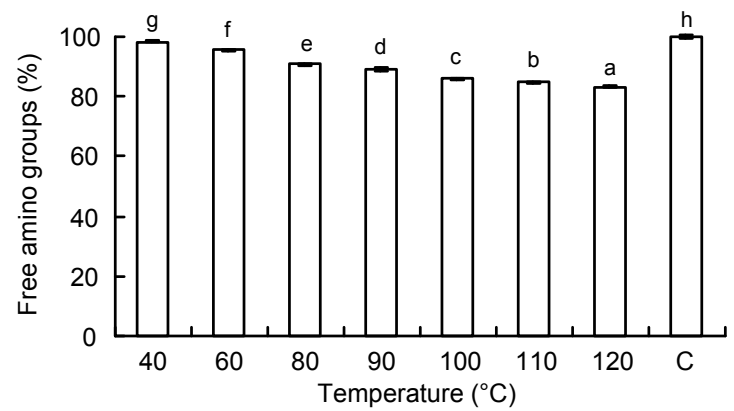

(b)

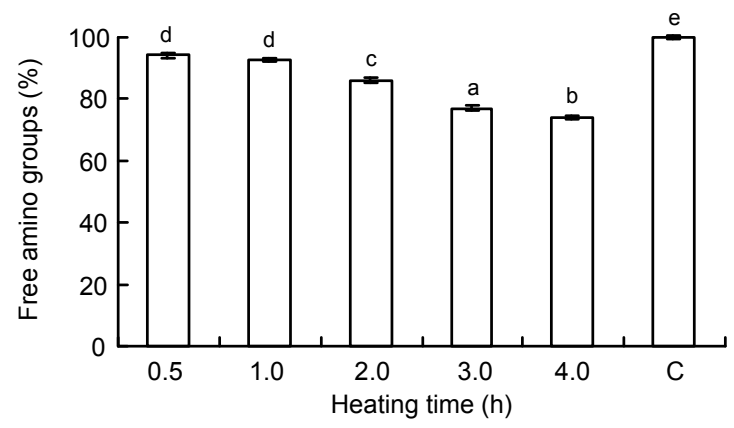

(c)

Fig. 2 Changes in free amino groups of ACE inhibitory peptides

(a) At different $\mathrm{pH}$ levels $(1.0-12.0), 100{ }^{\circ} \mathrm{C}$ for $1 \mathrm{~h}$ of heat treatment; (b) At different temperatures $\left(40-120^{\circ} \mathrm{C}\right), \mathrm{pH} 7.0$ for $2 \mathrm{~h}$; (c) For different heating time $(0-4 \mathrm{~h})$ at $100{ }^{\circ} \mathrm{C}$ and $\mathrm{pH}$ 7.0. $\mathrm{C}$ denotes the ACE inhibitory peptides without heat treatment. Values are expressed as mean $\pm \mathrm{SD}, n=3$. Different letters above the bars are significantly different $(P<0.05)$

solution is light yellow. However, heat treatment conditions probably promote the peptides to react with small amounts of sugars to form browning products. This would potentially darken the color of the peptide solution. Therefore, by detecting color changes, it may be possible to assess how different heat treatments affect ACE inhibitory peptides.

The changes in color of ACE inhibitory peptides under different $\mathrm{pH}$ values (1.0 to 12.0$)$ at $100{ }^{\circ} \mathrm{C}$ for
$1 \mathrm{~h}$ are shown in Fig. 3a. The $b^{*}$ values of ACE inhibitory peptides across this $\mathrm{pH}$ range were significantly different $(P<0.05)$ to that of unheated peptides. This showed that heat treatment could darken the color of ACE inhibitory peptide solutions. The $b^{*}$ values of peptides heated at $\mathrm{pH}$ levels of 1.0 and 2.0 were higher than those of peptides heated in the $\mathrm{pH}$ range of 3.0 to $8.0(P<0.05)$. This was probably due to strong acidity contributing to the formation of more chromatic compounds by chemical oxidation and aggregation of ACE inhibitory peptides. However, when the peptides were heated in $\mathrm{pH}$ range of 3.0 to 8.0 , there were no significant differences in the $b^{*}$ values $(P>0.05)$. Nevertheless, ACE inhibitory peptides became darker and browner with increasingly alkaline $\mathrm{pH}$ values (9.0 to 12.0 ). Under alkaline heat treatment, amino groups of ACE peptides may have easily reacted with a few carbonyl groups present in the peptide samples to form browning products of the Maillard reaction, such as melanoidin. Thus, excessive alkaline heat treatment markedly changed the color of the bovine casein ACE inhibitory peptides.

Compared to unheated peptides, the $b^{*}$ values of ACE inhibitory peptides did not differ significantly in the temperature range of 40 to $80{ }^{\circ} \mathrm{C} \quad(P>0.05)$ (Fig. 3b). However, there was a significant increase in the $b^{*}$ value of samples heated from 90 to $120{ }^{\circ} \mathrm{C}$ $(P<0.05)$. Changes in the color of ACE inhibitory peptides under different heating times $(0.5-4.0 \mathrm{~h})$ at $100{ }^{\circ} \mathrm{C}$ and $\mathrm{pH} 7.0$ are shown in Fig. 3c. The color of the peptides derived from bovine casein gradually darkened as the heating time increased up to $4 \mathrm{~h}$ $(P<0.05)$. These results proved that high temperature and prolonged heating time can accelerate the browning intensity due to the Maillard reaction in ACE inhibitory peptides.

In this study, the loss of ACE inhibitory activity of bovine casein-derived peptides was positively correlated with increasing dark color during heat treatment. Li et al . (2010) reported that the ACE inhibitory activities of extracts from Chinese commercial fermented soy paste were significantly correlated with their color. Okamoto et al. (1995) showed that soy sauces with light color showed lower ACE inhibitory activity than those with dark color. Thus, the ACE inhibitory activities of food ingredients may be correlated with their color. 


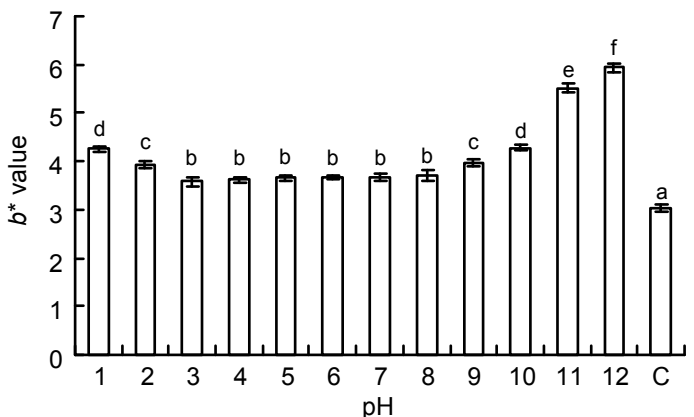

(a)

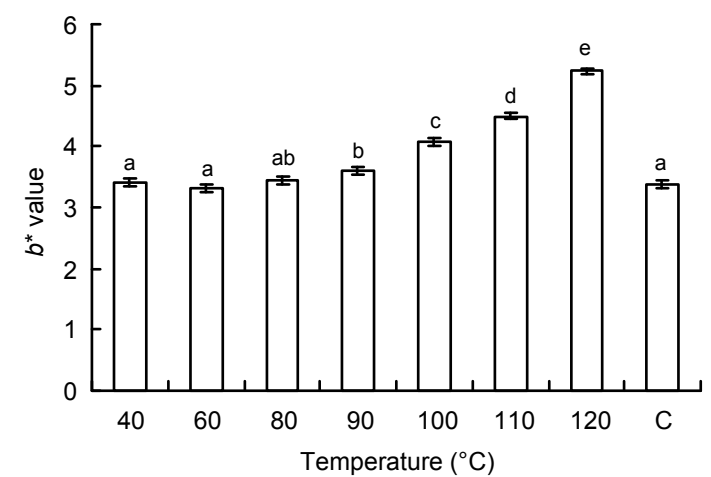

(b)

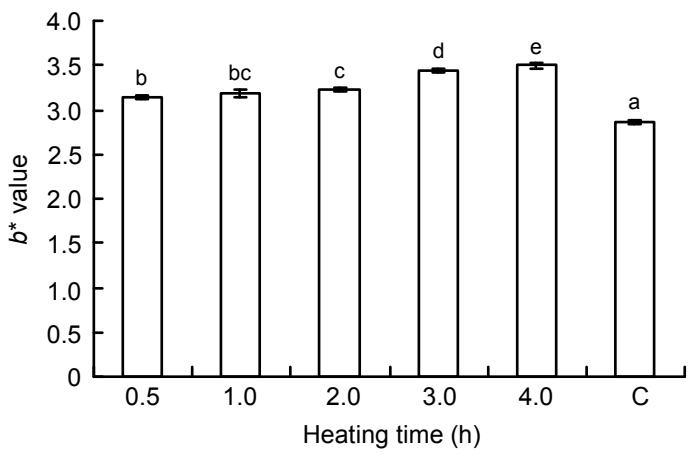

(c)

Fig. 3 Changes in the color of ACE inhibitory peptides (a) At different $\mathrm{pH}$ levels (1.0-12.0), $100{ }^{\circ} \mathrm{C}$ for $1 \mathrm{~h}$ of heat treatment; (b) At different temperatures $\left(40-120^{\circ} \mathrm{C}\right), \mathrm{pH} 7.0$ for $2 \mathrm{~h}$; (c) For different heating times $(0-4 \mathrm{~h})$ at $100{ }^{\circ} \mathrm{C}$ and $\mathrm{pH}$ 7.0. $\mathrm{C}$ denotes the ACE inhibitory peptides without heat treatment. Values are expressed as mean $\pm \mathrm{SD}, n=3$. Different letters above the bars are significantly different $(P<0.05)$

\subsection{Cell viability of bovine casein-derived $\mathrm{ACE}$ inhibitory peptides}

Although some bioactive peptides have great potential as food functional ingredients, it is important to consider their safety and toxicity to ensure that they are suitable for being used in functional foods. To evaluate the cytotoxic effects of bovine caseinderived ACE inhibitory peptides, MTT assay was used to determine the cell viability. The effects of bovine casein-derived ACE inhibitory peptides unheated or heated for $5 \mathrm{~h}$ on the cell viability of Caco-2 and ECV-304 cell lines are shown in Fig. 4.

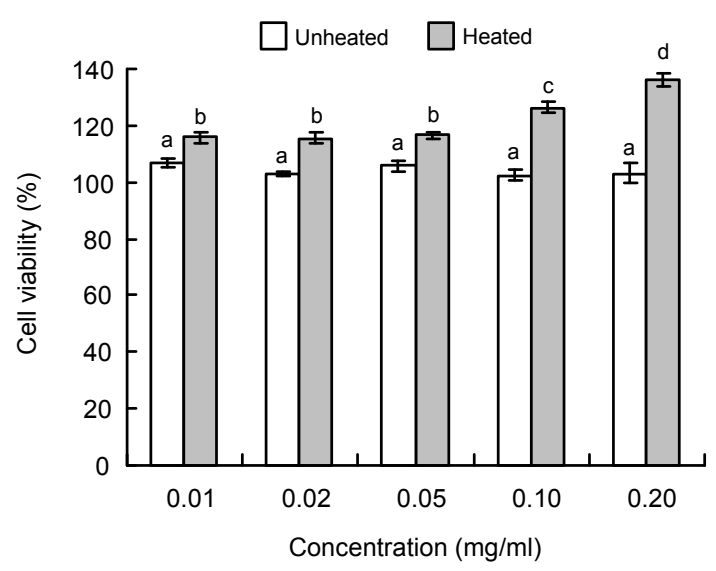

(a)

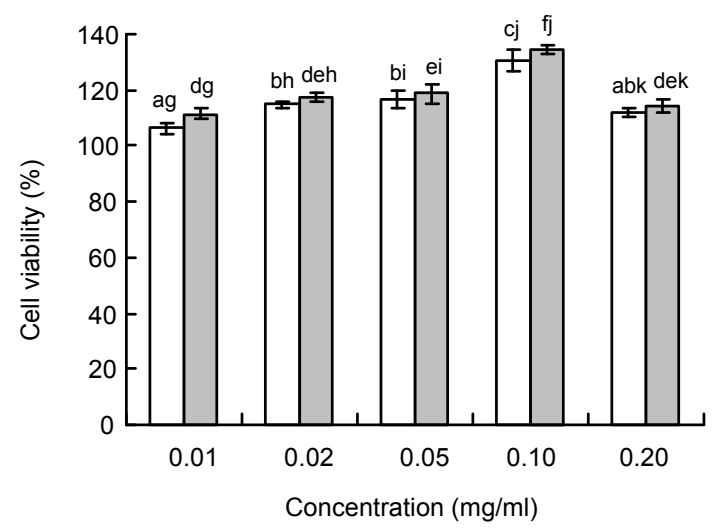

(b)

Fig. 4 Effects of ACE inhibitory peptides unheated or heated at $100{ }^{\circ} \mathrm{C}$ and $\mathrm{pH} 7.0$ for $5 \mathrm{~h}$ on cell viability

(a) Caco-2 cell line; (b) ECV-304 cell line. Values are expressed as mean $\pm \mathrm{SD}, n=6$. Different letters above the bars are significantly different $(P<0.05)$

Our results demonstrated that there were no cytotoxic effects of bovine casein-derived ACE inhibitory peptides on the two types of human cell lines (Caco-2 and ECV-304) after incubation for $48 \mathrm{~h}$ in the DMEM solution containing a range of concentrations of the peptides from 0.01 to $0.20 \mathrm{mg} / \mathrm{ml}$. Similar 
results were obtained by Qian et al. (2007), who proved that ACE inhibitory peptides from bullfrog (Rana catesbeiana Shaw) muscle protein showed no cytotoxicity to human embryonic lung fibroblast cell line MRC-5. There were also no deleterious cytochemical consequences (apoptotic, anti-proliferative or general cytotoxic effects) when a range of casein phosphopeptide preparations were added to human cancer cell lines (HL-60 and Caco-2 cells) and nonmalignant polymorphonuclear leukocytes (Hartmann and Meisel, 2004).

When Caco-2 cells were incubated in DMEM with unheated ACE inhibitory peptide samples at concentrations from 0.01 to $0.20 \mathrm{mg} / \mathrm{ml}$, no significant differences in cytotoxicity were found $(P>0.05)$ (Fig. 4a). Heating of ACE inhibitory peptide samples for $5 \mathrm{~h}$ increased the viability of Caco-2 cells $(P<0.05)$ compared to unheated samples. The viability of Caco-2 cells was significantly increased when the concentration of peptides heated for $5 \mathrm{~h}$ ranged from 0.05 to $2.0 \mathrm{mg} / \mathrm{ml}(P<0.05)$. The results indicate that heated ACE inhibitory peptides were probably decomposed into some smaller fractions which could be absorbed by the cells and which stimulated cell proliferation by enhancing DNA synthesis (Azuma et al., 1989; MacDonald et al., 1994).

However, there were no significant differences in the viability of ECV-304 cells between unheated and heated ACE inhibitory peptide samples $(P>0.05)$ across a range of concentrations from 0.01 to $0.20 \mathrm{mg} / \mathrm{ml}$ (Fig. 4b). This result showed that heated ACE inhibitory peptides promoted proliferation of Caco-2 cells, but not of ECV-304 cells. This may be due to the different cell lines having different sensibility to the anti-proliferative or stimulating effects of the ACE inhibitory peptides (Phelan et al., 2009).

\section{Conclusions}

Bovine casein-derived ACE inhibitory peptides were studied for the stability of their ACE inhibitory activity. Their free amino group content, color, and effects on cell viabilities of Caco-2 and ECV-304 were measured after heat treatment. Bovine caseinderived peptides could maintain ACE inhibitory ac- tivity with thermal treatment under acid, neutral, and weak alkaline conditions ( $\mathrm{pH} 1.0-8.0$ ), while strong alkaline conditions ( $\mathrm{pH} 9.0-12.0$ ) led to the loss of ACE inhibitory activity of the peptides. High temperatures $\left(110-120{ }^{\circ} \mathrm{C}\right)$ also resulted in the loss of ACE inhibitory activity. The free amino group content of ACE inhibitory peptides decreased markedly under thermal treatment in acidic or alkaline conditions. Alkaline heat treatment $(\mathrm{pH} 9.0-12.0)$ greatly darkened the color of the peptides. Both high temperature and prolonged heating time led to the loss of free amino groups and dark color of ACE inhibitory peptides. However, heated ACE inhibitory peptides showed no cytotoxicity to Caco-2 or ECV-304 cells. Therefore, when ACE inhibitory peptides are applied as functional food ingredients, it is necessary to avoid severe heat treatments during food processing and storage.

\section{Compliance with ethics guidelines}

Wei WU, Pan-pan YU, Feng-yang ZHANG, Hong-xia CHE, and Zhan-mei JIANG declare that they have no conflict of interest.

This article does not contain any studies with human or animal subjects performed by any of the authors.

\section{References}

Akıllıoğlu, H.G., Karakaya, S., 2009. Effects of heat treatment and in vitro digestion on the angiotensin converting enzyme inhibitory activity of some legume species. Eur. Food Res. Technol., 229(6):915-921. [doi:10.1007/ s00217-009-1133-x]

Atkinson, A.B., Morton, J.J., Brown, J.J., et al., 1980. Captopril in clinical hypertension. Changes in components of renin-angiotensin system and in body composition in relation to fall in blood pressure with a note on measurement of angiotensin II during converting enzyme inhibition. Br. Heart J., 44(3):290-296. [doi:10.1136/hrt.44.3. 290]

Azuma, N., Nagaune, S., Ishino, Y., et al., 1989. DNAsynthesis stimulating peptides from human $\beta$-casein. Agric. Biol. Chem., 53(10):2631-2634. [doi:10.1271/bbb1961. 53.2631]

Boye, J.I., Ma, C.Y., Ismail, A., et al., 1997. Molecular and microstructural studies of thermal denaturation and gelation of $\beta$-lactoglobulins A and B. J. Agric. Food Chem., 45(5):1608-1618. [doi:10.1021/jf960622x]

Chen, G.W., Tsai, J.S., Pan, B.S., 2007. Purification of angiotensin I-converting enzyme inhibitory peptides and antihypertensive effect of milk produced by proteasefacilitated lactic fermentation. Int. Dairy J., 17(6): 
641-647. [doi:10.1016/j.idairyj.2006.07.004]

Chen, J.W., Wang, Y.M., Zhong, Q.X., et al., 2012. Purification and characterization of a novel angiotensin-I converting enzyme (ACE) inhibitory peptide derived from enzymatic hydrolysate of grass carp protein. Peptides, 33(1):52-58. [doi:10.1016/j.peptides.2011.11.006]

Church, F.C., Swaisgood, H.E., Porter, D.H., et al., 1983. Spectrophotometric assay using $o$-phthaldialdehyde for determination of proteolysis in milk and isolated milk proteins. J. Dairy Sci., 66(6):1219-1227. [doi:10.3168/ jds.S0022-0302(83)81926-2]

Costa, E.L., Gontijo, J.A.D., Netto, F.M., 2007. Effect of heat and enzymatic treatment on the antihypertensive activity of whey protein hydrolysates. Int. Dairy J., 17(6): 632-640. [doi:10.1016/j.idairyj.2006.09.003]

Cushman, D.W., Cheung, H.S., 1971. Spectrophotometric assay and properties of the angiotensin converting enzyme of rabbit lung. Biochem. Pharmacol., 20(7): 1637-1648. [doi:10.1016/0006-2952(71)90292-9]

Ferreira, S.H., 1965. A bradykinin-potentiating factor (BPF) present in the venom of Bothrops jararaca. $\mathrm{Br} . \mathrm{J}$. Pharmacol. Chemother., 24(1):163-169. [doi:10.1111/j. 1476-5381.1965.tb02091.x]

Hartmann, R., Meisel, H., 2004. Caseinophosphopeptides and their cell modulting potential. Biofactors, 21(1-4):73-78. [doi:10.1002/biof.552210114]

Hwang, J.S., 2010. Impact of processing on stability of angiotensin I-converting enzyme (ACE) inhibitory peptides obtained from tuna cooking juice. Food Res. Int., 43(3):902-906. [doi:10.1016/j.foodres.2009.12.012]

Ichimura, T., Hu, J.N., Aita, D.Q., et al., 2003. Angiotensin I-converting enzyme inhibitory activity and insulin secretion stimulative activity of fermented fish sauce. $J$. Biosci. Bioeng., 96(5):496-499. [doi:10.1016/S13891723(03)70138-8]

Jang, A., Lee, M., 2005. Purification and identification of angiotensin converting enzyme inhibitory peptides from beef hydrolysates. Meat Sci., 69(4):653-661. [doi:10. 1016/j.meatsci.2004.10.014]

Jang, A., Jo, C., Lee, M., 2007. Storage stability of the synthetic angiotensin converting enzyme (ACE) inhibitory peptides separated from beef sareoplasmic protein extracts at different $\mathrm{pH}$, temperature, and gastric digestion. Food Sci. Biotechnol., 16(4):572-575.

Jiang, Z.M., Tian, B., Brodkorb, A., et al., 2010. Production, analysis and in vivo evaluation of novel angiotensin-Iconverting enzyme inhibitory peptides from bovine casein. Food Chem., 123(3):779-786. [doi:10.1016/j. foodchem.2010.05.026]

Korhonen, H., Pihlanto-Leppala, A., Rantamaki, P., et al., 1998. Impact of processing on bioactive proteins and peptides. Trends Food Sci. Technol., 9(8-9):307-319. [doi:10.1016/S0924-2244(98)00054-5]

Lee, J.K., Hong, S., Jeon, J.K., et al., 2009. Purification and characterization of angiotensin I converting enzyme inhibitory peptides from the rotifer, Brachionus rotundiformis. Bioresource Technol., 100(21):5255-5259. [doi:10.1016/j.biortech.2009.05.057]

Li, F.J., Yin, L.J., Cheng, Y.Q., et al., 2010. Angiotensin I-converting enzyme inhibitory activities of extracts from commercial Chinese style fermented soypaste. Jpn. Agric. Res. Q., 44(2):167-172. [doi:10.6090/jarq.44.167]

Li, G.H., Le, G.W., Shi, Y.H., et al., 2004. Angiotensin I-converting enzyme inhibitory peptides derived from food proteins and their physiological and pharmacological effects. Nutr. Res., 24(7):469-486. [doi:10.1016/j. nutres.2003.10.014]

López-Fandino, R, Otte, J., van Camp, J., 2006. Physiological, chemical and technological aspects of milk-proteinderived peptides with antihypertensive and ACEinhibitory activity. Int. Dairy J., 16(11):1277-1293. [doi:10.1016/j.idairyj.2006.06.004]

MacDonald, R., Thornton, W.H., Marshall, R.A., 1994. A cell culture model to identify biologically active peptides generated by bacterial hydrolysis of casein. J. Dairy Sci., 77(5):1167-1175. [doi:10.3168/jds.S0022-0302(94) 77054-5]

Okamoto, A., Hanagata, H., Matsumoto, E., et al., 1995. Angiotensin I converting enzyme inhibitory activities of various fermented foods. Biosci. Biotechnol. Biochem., 59(6):1147-1149. [doi:10.1271/bbb.59.1147]

Ondetti, M.A., Cushman, D.W., 1982. Enzyme of the renninangiotensin system and their inhibitors. Annu. Rev. Biochem., 51(1):283-308. [doi:10.1146/annurev.bi.51. 070182.001435]

Oshima, G., Shimabukuro, H., Nagasawa, K., 1979. Peptide inhibitors of angiotensin I-converting enzyme in digests of gelatin by bacterial collagenase. Biochim. Biophys. Acta Enzymol., 566(1):128-137. [doi:10.1016/0005-2744 (79)90255-9]

Phelan, M., Aherne, A., FitzGerald, R.J., et al., 2009. Caseinderived bioactive peptides: biological effects, industrial uses, safety aspects and regulatory status. Int. Dairy J., 19(11):643-654. [doi:10.1016/j.idairyj.2009.06.001]

Qian, Z.J., Jung, W.K., Lee, S.H., et al., 2007. Antihypertensive effect of an angiotensin I-converting enzyme inhibitory peptide from bullfrog (Rana catesbeiana Shaw) muscle protein in spontaneously hypertensive rats. Process Biochem., 42(10):1443-1448. [doi:10.1016/j. procbio.2007.05.013]

Rada-Mendoza, M., Villamie, M., Molina, E., et al., 2006. Effects of heat treatment and high pressure on the subsequent lactosylation of beta-lactoglobulin. Food Chem., 99(4):651-655. [doi:10.1016/j.foodchem.2005.08.039]

Roškar, R., Simončič, Z., Gartner, A., et al., 2009. Stability of new potential ACE inhibitor in the aqueous solutions of different pH. J. Pharm. Biomed. Anal., 49(2):295-303. [doi:10.1016/j.jpba.2008.11.029] 
Sheih, I.C., Fang, T.J., Wu, T.K., 2009. Isolation and characterisation of a novel angiotensin I-converting enzyme (ACE) inhibitory peptide from the algae protein waste. Food Chem., 115(1):279-284. [doi:10.1016/j.foodchem. 2008.12.019]

Tovar-Pérez, E.G., Guerrero-Legarreta, I., Farres-Gonzalez, A., et al., 2009. Angiotensin I-converting enzymeinhibitory peptide fractions from albumin 1 and globulin as obtained of amaranth grain. Food Chem., 116(2): 437-444. [doi:10.1016/j.foodchem.2009.02.062]
Wu, J.P., Ding, X.L., 2002. Characterization of inhibition and stability of soy-protein-derived angiotensin I-converting enzyme inhibitory peptides. Food Res. Int., 35(4): 367-375. [doi:10.1016/S0963-9969(01)00131-4]

Zhang, J.H., Tatsumi, E., Ding, C.H., et al., 2006. Angiotensin I-converting enzyme inhibitory peptides in douchi, a Chinese traditional fermented soybean product. Food Chem., 98(3):551-557. [doi:10.1016/j.foodchem.2005.06. 024]

\section{中文概要：}

本文题目: 牛乳酪蛋白源 ACE 抑制肽的稳定性和毒理特性研究

Stability and cytotoxicity of angiotensin-I-converting enzyme inhibitory peptides derived from bovine casein

研究目的：酸碱热处理对牛乳酪蛋白源血管紧张素转化酶（ACE）抑制肽的抑制活性、游离氨基、色泽 及其毒理特性的影响。

创新要点: 在 $\mathrm{pH} 9.0$ 12.0的热处理条件下, 牛乳酪蛋白源ACE抑制肽的抑制活性降低, 色泽加深。热处 理后的ACE抑制肽对Caco-2细胞和ECV-304细胞没有毒性作用。

研究方法: 以ACE抑制活性、游离氨基、色差值和细胞存活率为检测指标, 研究了酸碱热处理对 ACE抑 制肽的稳定性和毒理特性影响。

重要结论: 高温和碱性热处理能破坏酪蛋白源 ACE 抑制肽的稳定性（见图 1 3）。

关键词组：血管紧张素转化酶（ACE）抑制肽；热处理；稳定性；毒理特性 